\title{
ESTADO DE DIREITO E SEgURANÇA NACIONAL (*)
}

\author{
ALCIDES MUNHOZ NETTO $(* *)$
}

Sumário: 1. Introdução 2. Conceito de Estado de Direiło. 3. Os direitos humanos: a) era liberal; b) as contestações marxista, nazista e fascista; c) democracias contemporâneas. 4. Classificação das liberdades públicas. 5. As garantias dos direitos da homem e a Sizgurança do Estado. 6. Os riscos da incriminação. 7. Conceifo de Segurança Nacional. 8. Princípios básicos do Direito Penal: a) objetividade naturalística e jurídica; b) legalidade; c) culpabilidade; d) proporcionalidade da pena. 9. Garantias processuais. 10. Conclusões.

1. O objetivo deste trabalho é apontar os princípios básicos que, em um Estado de Direito democrático, devem orientar a incriminação de fatos atentatórios à Segurança Nacional. Trata-se de ensaio em estabeleorr os valores a serem penalmente tutelados, para a salvaguarda do Estado, em sua independência, estrutura e organização político-social. Mas, trata-se também, e sobretudo, de reafirmar os limites a que, neste campo, se deve sujeitar a atividade repressiva, para que não fique comprometida a realização dos direitos do homem, de que o próprio Estado deve ser o garantidor.

A esperança na restauração de um autêntico Estado de Direito, anunciada pelos agentes do poder e pela qual anseiam os mais expressivos setores da vida nacional, torna oportuna a revisão das leis que definem os crimes contra a segurança, máxime do Decretolei $898 / 69$. Elaborado às pressas, em momento de crise política, com o país governado por Junta Militar, o referido diploma ressente-se de inúmeras imperfeições, algumas das quais apontadas pelos seus próprios aplicadores. Com efeito, membros do Egrégio Superior Tribunal Militar têm reclamado dos excessos contidos naquele decreto, principalmente no que se refere ao desproporcionado rigor de suas penas. Sirva de exemplo a recente e oportuna entrevista do

(*) Tese apresentada à VII Conferência Nacional da OAB. Curitiba, 7 a 12 de maio de 1978.

(**) Professor Titular de Direito Penal da UFPR.. 
Ministro Augusto Fragoso, reconhecendo a necessidade de reformas, nem só quanto ao Decreto-lei 898/69, mas ainda quanto ao Decretolei 975/69 e à Lei 5786/72. Preconiza o ilustre General de Exército a codificação de todos os delitos políticos em um só diploma legal e sugere alterações liberalizantes como: a abolição de pena de morte; a suavização das penas privativas de liberdade, em səu quanfum e modo de execução; o integral respeito ao princípio da legalidade, com maior clareza na definição das condutas puníveis e neferências ao móvel político ou ao modo de execução, nos casos em que também constituam delitos comuns. (Folha de São Paulo, ed. 23/04/78, $1 .^{\circ}$ caderno, pág. 8). Como estas idéias correspondem ao pinsamento dominante nos meios jurídicos da nação, há um concurso quanto à necessidade de reforma das leis de segurança. Tal revisão é indispensável à anunciada abertura política, posto que, como proclamou BETTIOL, "é na disciplina penal e processual penal dos crimes políticos que $s$ deve procurar a pedra de toque do grau de democraticidade da polis Num clima político totalitário, todo crime tende, em razão de sua matéria ou em razão da intenção do agente, a transformar-se poiítico, de modo que não há lugar para - crime comum; num nægime de liberdade, pelo contrário, a całegoria dos crimes políticos tende a reduzir-se" (Instituições de Direito e Processo Penal, tradução de MANUEL DA COSTA ANDRADE, Coimbra, 1974, pág. 295).

Constituindo dever da Ordem dos Advogados do Brasil contribuir para o aperfeiçoamento de nossas instituições jurídicas (Lei n. ${ }^{\circ} 4.215 / 63$, art. 18, I), é de incontestável utilidade forneça sua VII Conferência Nacional subsídios à reformulação da lei acerca dos crimes políticos, proclamando os princípios que a classe gostaria de ver respeitados na futura legislação.

2. Sob um aspecto meramente formal, Estado de Direito é - que possui um sistema de leis expressamente estabelecidas. Tal formulação, de cru positivismo jurídico, é de todo insatisfatória. Qualificar como Estado de Direito toda organização política, que se regule por um conjunto de lis, implica em reconhecer tal qualidade aos sistemas totalitários. É que estes também dispõem de normas disciplinadoras da vida social, embora o autocrata, em última instância, as possa suprimir ou alterar, para que deixem de ter validaz geral ou não se apliquem a certos casos especiais. É de se enjeitar, pois, o pensamento de kELSEN, segundo o qual, do ponto de vista da ciência jurídica, o direito do regime nazista seria um Direito a ser lamentado, mas impossível de ser negado (Das Naturrecht in der politischen theorie, 1963, pág. 148, apud H. WELZEL, 
El problema de la validez del derecho, trad. de JOSÉ MARIA RODRIGUEZ PANIAGUA, Madri, 1971). As dramáticas vicissitudes que, neste século, abalaram os alicerces do mundo jurídico, através a instituição de Estado totalitários com sistemas cegamente baseados em sua validade exclusiva, acentuaram a necessidade de reconhecer-se que há leis que não consttiuam Direito, assim como há direitos que não adquirem a consistência de uma lei. Não constituem Direito as leis arbitrárias que só se impõem pelo poder de coação do Estado. A validez real da norma jurídica decorre de sua aceitação pela comunidade humana a que se destina. Segundo WELZEL, uma ordem imposta pela força não se converte em ordem jurídica, senão no momento em que se inclinem seu favor a maior parte das forças morais de um povo, isto é, quando o comportamento inequívoco da população reconhece-lhe, a propriedade de ser uma pauta orientadora da conduta (ob. cit., pág. 82). Constituem Direito, sem ser leis, os princípios diecorrentes da idéia da Justiça, baseada na autonomia moral do ser humana a quem se deve reconhecer uma dimensão jurídica que o Estado ou a coletividade não podem sacrificar ad nułum. Contrárias, pois ao Direito, ainda que como tal não reconhecidas pela lıi, são todas as situações que rebaixam o homem ao nível de objeto, utilizável por outros homens, como simples instrumento.

No sentido de considerar a autonomia do homem como um valor supra-estatal, coincidem as formulações jus-naturalitsas com as tecrias que dizduzem a idéia de Justiça, quer do princípio da igualdade quer da adequação dos meios para atingir um fim reto.

Na concepção iluminista do Direito Natural, fruto do racionalismo absoluto do século XVIII, todo o poder funda-se no corpo social e é instituído para o homem, cujos direitos são anteriores ao Estado, porque decorrentes da própria dignidade do ser humano. Desta forma, a liberdade, condição inerente ao ser racional, só comporta sacrifícios na estrita necessidade da vida coletiva, em função da liberdade dos demais. O jús naturalismo escolástico ou tomista é também deduzido da natureza racional do homem, mas identifica a idéia de Direito com a idéia de Justiça, como imperativo absoluto. Daí a conseqüência de que, sempre que a Justiça fonte substancial do direito positivo, às quais deve se curvar o legislador. "Trata-se de garantia para a liberdade, o reconhecer a dignidade da pessoa humana, cuja salvaguarda deve ser a aspiração constante de toda legisiação" (BETTIOL, ob. cit., pág. 21). Em perspectiva existencialista do Direito Natural, a pessoa humana é, por igual, o fulcro das preocupações. Não sendo mera parte de um sistema, o homem deve 
ser valorizado como ser singular. Em desfavor do sistema há de resolver-se o conflito de deveres, sempre que o homem seja chamado a escolher entre valores que lhe são inerentes e imposições do direito positivo, porque "a pessoa humana é o valor cultural supremo, num dado momento hisłórico" (idem, pág. 23).

Fora dos quadros do jus-naturalismo, proclama-se que "quando na formulação do direiło positivo se deixa de lado, conscientemente a igualdade, então não estamos só ante uma lei que esłabelece um Direito defeituoso, senão ante um caso de ausência do Direito. Porque não se pode definir o Direito, inclusive o direito positivo, senão dizendo que é ordem estabelecida com o sentido de servir à Justiça" (GUSTAV RADBRUCH, Leis que não são Direito e Direito acima das Leis, tradução de J. M. RODRIGUEZ PANIAGUA, pág. 14). Sob outro prisma, afirma-se que a melhor maneira de conceituar a Just ça, a cuja idéia deve curva-se o juiz é dada pela chamada teoria finalista: uma ação é correta juridicamente quando constitui um meio porporcionado, correto, não reprovável, para a consecução de um $\mathrm{f}: \mathrm{m}$ reto. Ao inverso, nenhuma ação, nem a do legislador, pode ser correta juridicamente, se se propõe a um fim em si mesmo incorreto, ou se se proprõe alcançar um fim cornəto, com meios desproporcianados, ou incorretos (cfr. EBERARD SCHMIDT, a lei e os juízes, trad. de J.M. RODRIGUEZ PA.NIAGUA, pág. 57). O conteúdo da fórmula é fornecido por valorações materiais, segundo as idéias, costumes e cultura jurídica de formação cristã e sobretudo pæla idéia moral do homem em sua caracterização como ser autônomo.

Todas as construções acima, assentes embora em premissas distintas, acentuam que $\circ$ Direito não pode nunca parder de vista $\circ$ respeito à personalidade do homem, concebida com a sua autonomia e liberdade de decisão. Desta forma, substancialmente, como Estado de Direito, só poda ser considerado o que se auto-limita para respeitar os direitos individuais, ou seja, os direitos que constituem, no dizer de RUY, "ao derredor de cada um de nós, uma esfera sagracla, que à autoridade social não é lícito penetrar sem violência ou injustiça" (O Papa e o Concílio, pág. 109). Sendo o arbítrio político incompatível com a liberdade individual, "pode-se dizer que o traço político pelo qual se reconhece o Estado de Direito é o grau de garantia de que são cercados os indivíduos" (QUEIROZ LIMA, Teoria do Estado, pág. 57). Em outras palavras, no Estado de Direito, a autoridade deve ser posta a serviço das liberdades da pessoa humana, sem prejuízo para os superiores e legítimos interesses da coletividade (ARY FLORENNCIO GUIMARÃES, Liberdades Fundamentais da 
Pessoa Humana em face do Estado, in Anais do $1 .^{\circ}$ Congresso Interamericano do Ministério Público, São Paulo, 1956, vol. II, pág. 336).

3. Se o Estado de Direito é, em substância, o que respeita as liberdades individuais, importa fixar-Ihe o conteúdo. Trata-se de preliminar importante para estabelecer, axiologicamente, os bens e interesses, para cuja realização o podier público deve, a um só tempo, auto-limitar a sua ação repressora e dispensar-lhes eficiente tutela jurídica.

a) Por largo tempo não se reconheceu as liberdades do homem. Orgânica e politicamente, o Estado antigo era um todo absolutista e despótico (FUSTEL DE COULANGES, A Cidade Antiga, vol. I, pág. 348). Embora o cristianismo haja estabelcido princípios favoráveis à liberdade, decorrentes da igualdade e da sacralidade do homem, a era liberal só se iniciou no século XVIII. Após os precedentes anglo-saxões consubstnciados na Magna Charła Libertałum (1215), na petição de direitos (1628), na instituição do habeas corpus (1679) e no bill of rigths (1689), o liberalismo encontrou consagração na nascente República dos Estados Unidos da América e na intelectualizada nação francesa. A Declaração de Direitos da Virgínia e a Declaraçâo da Independência Americana (1776), assim como a Declaração Francesa dos Direitos do Homem e do Cidadão, constituiram-se em profissões de fé no Direito Natural e na filosofia individualista da época. Em linhas gerais, reconheceram a pré-existência de direitos humanos universais e permanentes e a conseqüente necessidade dos Estados se organizarem para garanti-los. Tais direitos são, nem só os inerentes à autonomia humana (a igualdade, a liberdade e a propriedade), como os que decorrem da vida em sociedade, mas destinam-se a garantir aqueles (direito ao voto, à legalidade dos impostos, à igualdade de acesso aos cargos públicos, à liberdade de expressão). A tais direitos vieram acrescer-se as liberdades de comércio, de reunião e de petição (JEAN ROCHES, Libertès Publiques, $3 .^{a}$ ed., pág. 11).

b) Consagrados pelo direito positivo do mundo civilizado, os direitos do homem permaneceram incontestes até o fim da primeira guerra mundial. Iniciaram-se, então, as tentativas de negar-lhes a transcedência, com o socialismo-marxista, ○ nazismo e o fascismo. O comunismo reputou-os direitos formais, só acessíveis aos ricos e contrapôs-lhes, como direitos verdadeiros, os direitos econômicos (ao trabalho, seguro, férias, etc.) e as liberdades intelectuais (consciência, religião, palavra, imprensa, reunião e associação). Ao nacional socialismo, os direitos do homem não tinham qualquer razão de subsistir. Ligados entre si por vínculos de sangue, os indivíduos identificarse-iam, sendo absorvidos pela comunidade nacional e racial. Tal co- 
munidade era o critério supremo de valoração das condutas do homem, destinado tão só a exercer as funções que o todo lhe atribuísse. Para o fascismo, o fulcro da realidade social e política transferira-se do homem para o Estado. Este reivindicava para si "um poder originário e autônemo, face à vontade dos indivíduos, em todos os setores da atividade política" (BETTIOL, ob. cit., págs. 76 e 91).

As apontadas negações totalitárias aos direitos humanos tradicionais não lhes infirmaram, contudo, a importância. Após a derrota, na segunda grande guerra, da Alemanha e da Itália, as duas nações voltaram aos padrões liberais e neles se mantêm, sem indícios de regressões às negras épocas passadas. Paralelamente, vêm desaparecendo os regimes de inspiração nazi-fascista, a exemplo do que aconteceu com Portugal e com a Espanha. No bloco oriental, é permanente o descontentamento $\mathrm{ccm} \circ$ totalitarismo do Estado. Apesar do rigor da repressão, levantou-se a Hungria em 1956 e estão em revolta até hoje os intelectuais oprimidos. É que na prática não prevalecem, sequer as declarações dos direitos econômicos e das liberdades intelectuais constantes das constituições das repúblicas populares. Aos trabalhadores nega-se o direito de greve, a pretexto de que não mais existem os que os exploravam. O direito de propriedade circunscreve-se às pequenas economias resultantes do trabalho pessoal. E o exercício das liberdades intelectuais é condicionado pelos interesses do partido único, que, monopolisticamente, se rotula o guarda avançado das classes obreiras. Em suma, na concepção marxista, os direitos e liberdades não são concedidos aos indivíduos para que exerçam suas próprias opções, pois estas estão "irrevogavelmente presas à sociedade comunisła e foda utilização da liberdade que se desviar deste rumo pode ser condenada como ilícita (JEAN ROCHE, ob. cit., pág. 21).

c) A preocupação dominante, na época das declarações de direitos, era a de substituir as estruturas dos Estados de Polícia, pelo Estado de Direito. À burguesia de então interessava que toda a atividade dos órgãos públicos estivesse expressamente regulada por precisos dispositivos legais, para a salvaguarda dos direitos do cidadão. Este sentido nitidamente individualista impediu que também fossem contemplados os direitos sociais, tendentes a propiciar melhores condições de existência acs menos favorecidos e a regular, de forma justa, os conflitos entre o capital e o trabalho. É que o reconhecimento de tais direitos implicava em admitir a intervenção do Estado em setores que os liberais do século XVIII julgavam interditados à ação do poder. Após a segunda guerra mundial, acentuou-se a necessidade de estender a um maior número o exercício de liberdades individuais. Cedendo ao império de novas condições de vịda, as Constituições 
despreenderam-se da rígida concepção liberal do Estado, para distender o seu âmbito "a todos os sełores em que se faça precisa a ação equilibradora do poder público, no sentido de reger a vida coletiva, não somente no seu aspecto político, senão também no econômico e até no moral" (SEABRA FAGUNDES, $O$ Controle dos Atos Administrativos, 2. ${ }^{a}$ ed., págs. 11 e 12). Sem negar a transcendência dos direitos individuais, os sistemas democráticos os adaptaram às novas necessidades, ao mesmo tempo em que reconheceram direitos novos. As adaptações consistiram em: condicionar o direito de propriedade ao interesse social; em sujeitar a liberdade de comércio à regulamentação crescente, à vista do bem comum e em admitir, como decorrência da liberdade de associação, a sindicalização dos trabalhadores e a formação de partidos políticos. Os direitos novos expressaram-se nos direitos relacionados ao emprego (dissídios individuais e coletivos, greve e formação profissional) e na igualdade profissional e política da mulher. Desta forma, as organizações democráticas adquiriram um cunho social, que lhes permitiu superar as contestações totalitárias, posto que, em lugar de negarem os clássicos direitos individuais, a pretexto de se constituirem em privilégios da fortuna, os tornaram acessíveis a todas as camadas da população, reafirmando, assim, a supremacia da pessoa humana, sobre os outros valores que ao Estado incumbe atender. Este é, incontestavelmente, o fundamento básico das democracias ocidentais. Sua justificação personalista as distingue das democracias populares. "No ocidente a democracia é referida ao "homem pessoa", no sentido de que ele tem um valor e um signifíicado anterior e independentemente da sua inserção no coletivo; ao contrário, nos países socialistas, a única realidade ontológica é o "homem massa", o indivíduo inserido na coletividade, na classe ou na categoria a que pertence" (BETTIOL, ob. cit., pág. 97).

4. Segundo JEAN ROCHE (ob. cit., pág. 6), os direitos humanos ou liberdades públicas podem ser, atualmente, classificados em fundamentais e complementares. As liberdades fundamentais compreendem: 1) ○ princípio da igualdade, como condição primeira para prevenir a opressão; 2) as liberdades da pessoa, isto é, aquelas que garantem a sua integridade e a sua autonomia; 3) os direitos políticos, de votar e ser votado, que asseguram ao indivíduo a sua participação nos negócios; 4) o direito de propriedade, posto que nada sustenta mais a liberdade do indivíduo que a posse de seus bens. Como liberdades complementares são consideradas aquelas necessárias ao exercício das liberdades fundamentais. Não se trata de liberdades secundárias, mas de condições que dão efetividade aos demais direitos. Compreendem, portanto, as liberdades de pensamento (liberdade de imprensa, de religião, de associação, de reunião, etc.) e uma gama 
de direitos econômicos e sociais, que criam ou melhoram as condições materiais da liberdade (direito ao trabalho, direito sindical, direito de greve, liberdade de comércio e de indústria, no sentido moderno).

,A classificação acima parece mais satisfatória do que as que distinguem entre direitos individuais e direitos sociais, ou entre liberdades formais e liberdades reais. É que os direitos fundamentais e os direitos complementares são referidos ao homem e não ao corpo social, ou à classe, o que permite reduzir às duas categorias todas as liberdades públicas constantes da Declaração Universal dos Direitos do Homem da ONU (1948), de que o Brasil é subscritor.

5. Sem que o exercício das liberdades públicas seja assegurado de modo eficaz, resta'm, obviamente, ilusórias as suas enunciações em documentos internacionais ou em textos de cartas políticas. Destarte, tão importante quanto enumerar os direitos do homem, - aparelhá-los de efetivas garantias.

Ainda não se concretizou o velho sonho de estabelecer uma proteção internacional aos direitos do homem, de modo a fazê-lo um verdadeiro cidadão do mundo (GUETZÉVITCH, As Novas Tendências do Direito Constitucional, São Paulo, 1933, pág. 179). Apesar da abundância de declarações, convenções, tratados e protocolos, o Direito das Gentes não logrou tornar obrigatórios os textos asseguradores das liberdades humanas, por falta de mecanismos para jurisdicionais e jurisdicionais que sancionem as suas violações. Mesmo para as populações dos países do Velho Mundo, que ratificaram a Convenção Européia dos Direitos do Hómem (1950), a tutela internacional é limitada. Embora instituídos no documento uma Comissão e um Tribunal de Direitos do Homem (art. 19), tais órgãos não podem conhecer sempre de queixas por ofensas a liberdades públicas, posto que atuação de ambos depende do consentimento dos Estados acusados (arts. 25 e 46).

A tutela aos direitos do homem tem de ser buscada, assim, internamente, na organização de cada Estado. Nos regimes democráticos, as liberdades públicas contam com garantias políticas e com garan'ias jurisdicionais.

De um modo geral, as garantias políticas decorrem quer do direito de crítica reconhecido aos cidadãos, quer do sistema constitucional adotado, quer, ainda, da influência da opinião pública sobre os governantes. O direito de crítica implica nem só no direito de petição, como no de estabelecer grupos que pressionem os órgãos estatais. No sistema constitucional, o princípio da separação e independência dos poderes desempenha o mais importante papel na salvaguarda das liberdades. A influência da opinião pública manifesta-se

a

la

g

q

v

tr

s!

St

r

I€

N

d

a

ti

d

d

si

Ci

g

$p$

$p$

r

b

d

d

1.

st

e

çí

ir

SE

d.

C

p

oI

d

sf

to

p 
através de referendos e de eleições, desde que sejam livres. Ao lado destas garantias políticas genéricas certos Estados contam com garantias políticas específicas. É o que ocorre na Suécia e na França, que possuem órgãos especialmente destinados a fiscalizar a observância dos direitos do homem, pela administração pública e pelos tribunais, com total independência em face do poder político e possibilidade de advertir, repreender e responsabilizar criminalmente seus agentes, pelos abusos que cometam. $\bigcirc$ ombudsman suéco e o médiateur francês desempenham estas funções, o primeiro como delegado do parlamento e o segundo por investidura do Conselho de Ministros, com mandato de seis anos e amplas imunidades (Lei 73-6, de 3 de janeiro de 1973).

As garantias jurisdicionais, que, por motivos óbvios, pressupõem a independência dos juízes, consistem nem só no controle da constitucionalidade das leis e dos atos administrativos, à vista das liberdades públicas asseguradas aos cidadãos, como também na faculdade de impor sanções disciplinares e penais aos funcionários responsáveis por violações, bem como de obrigar a reparação dos danos causados.

Também como garantia dos direitcs do homem, situa-se a segurança do Estado. Este, quando suas instituições são liberais, é o primeiro garante das liberdades dos cidadãos (JEAN ROCHE, ob. cit., pág. 39). Efetivamente, o Estado não é um fim em si mesmo, mas meio de promover a felicidade de seus súditos, assegurando-lhes o bem-estar moral e material. Para isto - que o Estado reconhece os direitos individuais, a cujo serviço coloca a coação física de que dispõe (ver ATALIBA NOGUEIRA, O Estado é Meio e não Fim, pág. 153). No desempenho dessa alta missão, é preciso que o Estado não se deixe destruir e mantenha sua independência, bem como o pleno e normal funcionamento de suas instituições.

Nesta perspectiva, única adequada às democracias, a incriminação de fatos atentatórios à Segurança Nacional apresenta-se como instrumento de defesa da liberdade. O Estado não pode tolerar, sem negar-se a si próprio, a atividade dos que, valendo-se das liberdades que ele assegura, queiram terminar com a própria liberdade. O dogma de que "não há liberdade contra a liberdade" fundamenta, pois, a repressão dos delitos dirigidos contra o Estado, como unidade orgânica das instituições políticas e sociais e garante dos direitos dos cidadãos. A legitimidade em incriminar condutas contrárias à segurança externa ou interna do Estado decorre também do constitucionalismo, isto é, do princípio de que, só por meios jurídicos, pode ser reformada a estrutura do Estado. O emprego de meios 
anormais para alterar as instituições, estabelecidas pelo povo, através de legítimos representantes, livremente escolhidos, constitui, pois, violação ao direito da maioria, de manter a ordem político-social por ela adotada.

6. Mas, paradoxalmente, ao mesmo tempo em que é garantia da liberdade, a repressão dos atentados à Segurança Nacional também apresenta graves perigos aos direitos do homem. Isto porque nem sempre a incriminação parte do conceito exato de Segurança Nacional e observa os princípios democráticos básicos do Direito Penal e Processual Penal. Como adverte JEAN ROCHE (ob. cit., pág. 39), há "o perigo de uma extensão abusiva da noção de atentado à segurança do Estado, que inelutavelmente conduz à repressão de delitos de opinião (Estados autoritários ou totalitários). Então, não se esiará mais prołegendo o Estado, como pessoa moral estática no interesse geral, e sim defendendo determinada concepção política". E há ainda "o perigo de se recorrer a jurisdições e procedimentos de exceção", posto que "a repressão dos ałentados à segurança do Estado, em vista da importância da causa, é muitas vezes organizada com menosprezo às garantias de direito comum".

Na verdade, a punição dos delitos políticos já representou um dos mais sombrios capítulos de penalidade. Segundo QUINTANO RIPOLLES (Curso de Derecho Penal, Madri, 1963, pág. 461), é relativamente fácil assinalar uma linha evolutiva da criminalidade política: parte do conceito sacral de crime político como sacrilégio (antigo oriente); integra-se totalitariamente à figura do lesa-majestade dos absolutistas; num sentido oposto de privilégio, laiciza-se com os liberais do século XIX; finalmente, recrudesce com a proliferação da delinqüência anarquista. No direito comparado, a delinqüência política deixou de merecer a auréola, um tanto romântica, de privilégio, que outrora ostentava. É de SEBASTIAN SOLER a observação de que "a história ałual tem mostrado energicamente à democracia o resultado de sua complacência, porque, ao lado dos levantes mais ou menos caseiros, teve de defrontar-se com a ameaça não apenas teórica de uma destruição. E os que trouxpram esta ameaça estão muito longe do perfil românłico e idealista do defensor das liberdades do povo traçado pela doutrina. Em geral se trata de meras formas de abuso fraudulento ou violento do poder, para negar diretamente a vontade da maioria, já burlando-a com a introdução da fraude como sisłema eleitoral permanente, já torcendo-a demagogicamente com sistemas de "panen et circense", já finalmente, dissolvendo-a pelo terror e ałé por aniquilamento małerial" (Derecho Penal Argentino, vol. V. B. Aires, 1956, pág. 18).

lit

pc

gà

la:

$d e$

ga

$\mathrm{mi}_{\mathrm{i}}$

Se

ati

$\mathrm{mi}$

mi

re

pc

tel

int

46

fir

do

da

pe

mi

atı

to.

vo

rui

té

do

SS

me

go

De

SO,

na

ag

pú

de

Al.

ça 
Contudo, precisamente porque a eficiente repressão dos delitos contra a Segurança Nacoinal deve inspirar-se na defesa dos postulados democráticos (soberania do povo, divisão dos poderes e garantia dos direitos individuais), redobradas devem ser as caut las legislativas, no sentido, nem só de evitar que a função penal degenere de instrumento da Justiça em meio de opressão e vingança, como também de não castigar atos de criminalidade problemática.

7. O primeiro cuidado deve ser o de precisar o que seja Segurança Nacional.

A técnica moderna distingue entre os ataques ao Estado e os ataques ao sistema. No totalitarismo de cunho nacional-socialista ou marxista, manifestou-se a tendência de equiparar os conceitos, assemelhando os ataques contra a existência ao Estado aos contra o regime imperante. Trata-se de valores perfeitamentı diferenciáveis, porque os primeiros afetam a vida do Estado e da pátria, no que tem de permanente, enquanto que os segundos vulneram tão só interesses acidentais de regime político (cfr. RIPOLES, ob. cit., pág. 465). Segurança Nacional, assim, não é o que os governantes definam como tal em determinada conjuntura política. Segundo o saudoso Ministro ALIOMAR BALEEIRO, "Segurança Nacional envolve toda matéria pertinente à defesa da integridade do território, independência, sobrevivência e paz do país, suas instifuições e valores materiais ou morais contra ameaças internas e externas, sejam elas atuais ou imediałas, ou ainda em estado potencial próximo ou remoto... Os dineitos e garantias individuais, o federalismo e outros alvos fundamentais da Constituição ficarão abalados nos alicerces e ruirão se admitirmos que representa Segurança Nacional toda a matéria que o Presidente da República declarar que o é, sem oposição do Congresso" (in voto no R.E. 62.731, RTJ., vol. 45, pág. 559 e ss.).

Não é democrático, portanto, definir Segurança Nacional "como a garantia da consecução dos objetivos nacionais, contra antagonismos tanto internos como externos", a exemplo do art. $2 .^{\circ}$, do Decneto-Lei 898/69. Quem estabelece os objetivos nacionais é, consoante a Constituição da República, o Conselho de Segurança Nacional (art. 89, n. ${ }^{\circ}$ I). Como tal órgão é composto exclusivamente por agentes do Poder Executivo (Presidente e Vice-Presidiente da República e Ministros do Estado - art. 88), a fórmula encerra o risco de confundir obejtivos nacionais, como interesses governamentais. Além disso, como pondera HELENO CLÁUDIO FRAGOSO, segurança não é garantia, mas estado: se quisermos um estado de garan- 
tia, mas não pode ser garantia para alguma coisa "e os antagonismos são típicos de um regime democrático. Só as ditaduras não os toleram" (Jurisprudência Crimnal, 1973, vol. II, n. ${ }^{\circ} 29$, págs. 41 e 42).

Sob outro prisma, o próprio exame das leis brasileiras, em matéria e crimes contra a Segurança Nacional, conduz a que as diversas figuras delituosas nelas definidas podem sier classificadas nas seguintes categorias: a) crimes contra a personalidade internacional do Estado, abrangendo fatos que são lesivos à sua soberania ou independência, como provocação de guerra, espionagem e violação da neutralidade; b) crimes contra a personalidade interna do Estado, que lesam seus interesses, relativos à defesa da ordem constitucional; da incolumidade das funçõies do Estado da dignidade de seus órgãos; da inviolabilidade dos representantes máximos dos poderes da República; do decoro da Nação e do respeito aos seus símbolos; dos crimes contra Estados estrangeiros, capazes de afetar as relações po Brasil com outros países, mercê de ofensas ao direito de respeito recíproco, assim como as violações de imunidades de representantes de nações estrangeiras; d) crimes contra os direitos políticos do cidadão (Lei n. $.^{\circ} 1.802 / 53$, arts. $8 .^{\circ}$ e 23 ), compreendidos como tais a oposição a funcionamento de partido político e a ofensa oa coação por motivos doutrinárias. Nesta categoria poderiam ser incluídas as coações, violências, fraudes e corrupões contra eleitores, bem como a defraudação das votações e apurações. São fatos que afetam direitos políticos individuais, embora, entre nós, definidos por lei diversa da dos crimes políticos, isto é, pelo Código Eleitoral (lei n. $0^{\circ} 4.737 / 65$, arts. 289 a 335). É que em relação aos crimes eleitorais, a tutela penal "é estahuída, primacialmente, t.o inferesse das instifuições representałivas, o que vale dizer: no sentido da regularidade da ałuação do Esłado segundo o regime democrárico indireto, cujo êxito está conceiłualmente subordinado ao voto popular na seleção da elite ou "right men" a que devem ser confiadlas a leaboração das leis e a suprema gestão da coisa política. Os crimes eleitorais, exałamente apreciados; não, por conseqüência, crimes contra o Estado ou contra a ordem política" (NELSON HUNGRIA, Comentários ao Código Penal, ed. 1949, vol. I, pág. 166, nota 44). A.s incriminações têm compreendido, além da consumação e da tentativa, via de regra equiparadas quot poenam, também atos preparatórios das ofensas mais graves, a exemplo do que acontece com o aliciamento de estrangeiros para a invasão do Brasil e com o incitamento público à violência .

Da própria especificação dos bens e interesses afetados pela criminalidade política, segundo o Direito brasileiro, pode-se concluir 
que Segurança Nacional é a incolumidade do Estado, em sua independência, soberania, estrutura constitucional, funcionamento e independência dos poderes, bem como a incolumidade dos direitos políticos do cidadão.

8. Estabelecida a genérica natureza dos crimes contra a Segurança Nacional, cumpre tratar dos limites a que, num Estado de Direito, deve se submeter o legislador, na seleção das condutas puníveis a este título. Tais limites são os decorrentes dos princípios básicos do Direito Penal democrático.

Uma análise da doutrina comparada permite fixar os atuais fundamentos do Direito Penal das democracias autênticas. A nosso ver, quanto aos crimes contra a Segurança Nacional, são importantes os seguintes princípios. 1) da objetividade naturalística e jurídica; 2) da legalidade; 3) da culpabilidade; 4) da proporcionalidade da pena.

a) Se o Estado de Direito tendo a assegurar ao indivíduo a inviolabilidade de sua esfera de autonomia, crime não pcde ser um acontecimento puramente interno, pois este não viola a esfera de autonomia de outrem. O Direito Penal democrático tem de ser objetivamente orientado no sentido de que a nuda cogitatio não pode constituir suporte de um delito. O crime deve ser algo que altera as condições preexistentes do mundo exterior, e portanto, um quid susceptível de percepção censória. Nisto reside o princípio da objetividade naturalística, que se liga a uma exigência de certeza e, portanto, de segurança jurídica, no interesse da liberdade individual. Só os regimes totalitários têm a pretensão de prescrutar a alma humana. A ação delituosa deve manifestar-se num fato objetivo, daí decorrendo também a impossibilidade de identificar o crime, como um modo de ser do agenie (BETTIOL, ob. cit.. págs. 79. 99, 124. 125 e 127).

Conseqüências da objetividade naturalística, no campo dos delitos políticos, são a impossibilidade de incriminar os pensamentos: cogitationis poenam nemo patitur, assim como de castigar alguém por professar ideologia diversa da dominante. Com o desdobramento do mesmo princípio, lícito não é privar o homem dos meios de informação que deseja, nem puní-lo pela posse de obras e livros com idéias inaceitáveis ao regime. $\mathrm{Na}$ atual lei de Segurança $\mathrm{Na}$ cional, justiça lhe seja feita, não há qualquer dispositivo que incrimine idéias ou a posse de material para formá-las. Persiste, no entanto, a censura de livros e periódicos, não limitada ao tempo de guerra ou ao estado de sítio, nem circunscrita à interdição de publicações pornográficas, ou de informações relativas à defesa nacional, ou de certos debates judiciários. A atual extensão da censura 
atenta contra a liberdade de imprensa, pois, nas democracias, afora as apontadas exceções, prevalece o princípio da liberdade de informação, com responsabilidade administrativa e penal, a posteriori, pelos abusos eventualmente cometidos.

Pelo princípio da objetividade jurídica, a existência do crime é subordinada à efetiva ou potencial lesão de um bem ou interesse tutelados pelo Direito. O comportamento delituoso não constitui puro ato de rebelião ou desobediência, como afirmaram os teóricos do totalitarismo penal. O crime é agressão a determinado valor. A identificação deste valor é que dá conteúdo à esfera de autonomia do indivíduo. O Direito Penal democrático é o Direito Penal do resultado (Erfolgsstrafrecht); contrapõe-se ao Direito Penal da vontade (Willenstrafrecht) do nacional-socialismo que, considerava o crime como a mera infidelidade à orientação política, ou seja, à vontade da Führung (BETTIOL, ob. cit., págs. 76, 80 e 118).

No que toca aos crimes contra a Segurança Nacional, o problema reside em que a objetividade jurídica destes é demasiadamente ampla. Isto porque, ao lado dos crimes políticos puros, que lesam ou ameaçam de lesão bens concernentes à segurança externa ou interna do Estado, como a independência nacional, a integridade do território, as relações do Estado com os demais Estados, à forma de governo e a formação e a atividade dos poderes, existem os delitos políticos relativos, que lesam ou ameaçam bens de direito comum, como a vida, a integridade física, a liberdade de locomoção, o patrimônio, etc., mas são considerados políticos, porque praticados em conexão com crimes contra a Segurança Nacional, ou porque são simultaneamente ofensivos da ordem político-social e de um bem jurídico privado (Nelson Hungria, ob. cit., vol. I, pág. 170).

b) A amplitude dos bens ou interesses jurídicos que podem ser afetados pelos crimes políticos, determina a necessidade de uma cuidadosa tipificação desta categoria de ilícitos. O princípio da legalidade, consubstanciado no dogma do nullum crimen, nulla poena sine praevia lege, assume particular relevância quanto aos crimes contra a Segurança Nacional. É necessário que a lei fixe, de forma precisa, qual o fator que justifica a inclusão de um crime comum entre os crimes políticos. A respeito, parece-nos que o melhor critério é o subjetivo, que atende à motivação política da conduta. Tal critério adapta-se ao Direito brasileiro, que, para efeitos de extradição, proibida, em princípio, para os crimes políticos (Const. Fed., art. 153, § 15), manda atender à preponderância da infração política ou da infração comum (Dec. Lei n. ${ }^{\circ} 394 / 38$, art. $\left.2 .^{\circ}, \S 1.\right)$. Ora, nos crimes políticos relativos, a preponderância só pode ser deduzida 
pelo fim último visado pelo agente. Em conseqüência, a infração de direito comum só deve ser erigida à categoria de crime contra a Segurança Nacional, se praticada com nítido móvel político. Sem isto, corre-se o risco de ampliar demasiadamente o campo desta categoria de crimes. Não faz sentido, por exemplo, considerar como delito contra a Segurança Nacional, o roubo de bancos praticado sem nenhuma motivação política, como faz o art. 27, do Decreto-Lei n. ${ }^{\circ} 898$, de 1969. Trata-se de crime comum contra o patrimônio, cuja repressão já decorre do Código Penal. Os crimes políticos resultantes de infrações de direito comum devem conter sempre, como elemento subjetivo do tipo, o fim de atentar contra a Segurança Nacional, correspondente, na nomenclatura tradicional, a um dolo específico (HELENO C. FRAGOSO, ob. cit., pág. 29).

Ainda quanto à tipificação de crimes contra a Segurança Nacio nal, cumpre atender à recomendação da Comissão Redatora do Código Penal Tipo para a América Latina, no sentido de que "as leis penais devem descrever fatos puníveis de maneira inequívoca, sem deixar dúvidas sobre sua proibição". Isto é essencial no Estado de Direito, em que as relações entre a autoridade e a liberdade devem estar claramente definidas. A indeterminação do conteúdo do crime pode suscitar verdadeiras formas de arbítrio por parte do magistrado. Daí a importância em fixar, que o princípio da legalidade não se limita à exigência da anterioridade da lei incriminadora, mas impõe também ao legislador o dever de não formular tipos abertos, entendidos como tais, aqueles em que o enunciado da conduta típica deixa margens a incertezas na sua interpretação (ANIBAL BRUNO, Direito Penal, tomo IV, pág. 41). Necessário, portanto, evitar a inclusão no tipo de elementos normativos, cujo sentido não se deduz prontamente, mas tem de ser apreendido através de particular apreciação por parte do juiz e que trazem consigo o germe da imprecisão (idem).

A vigente lei de Segurança Nacional contém vários tipos abertos, a exemplo do que ocorre com o seu art. 45, que incrimina a ação de "fazer propaganda subversiva". Como não há descrição do que seja tal propaganda, podem ser enquadradas neste dispositivo as mais variadas situações, de acordo com o paladar do juiz. Ora, tipos semelhantes suscitam graves problemas jurídico-políticos, que se podem sintetizar no problema da discricionaridade. Pela elasticidade da configuração, enseja-se a elasticidade da repressão (SEABRA FAGUNDES, Direitos do Homem, a Ordem Pública e a Segurança Nacional, 1974, pág. 4). Numa lei que pretenda tutelar a liberdade do indivíduo, os elementos descritivos devem prevalecer sobre os 
normativos, a fim de que nem tudo seja remetido para a concreta decisão do magistrado (BETTIOL, ob. cit., pág. 116).

c) A efetiva averiguação da culpa lacto sensu é também uma exigência da liberdade política. Trata-se do momento caracteristicamente pessoal da imputação punitiva, pois através do juízo da culpabilidade é que se pode estabelecer se, pela perpetração de um fato típico, deve ser dirigida uma censura a seu autor. Há uma correlação íntima entre o princípio da legalidade e o princípio da culpa. Pelo primeiro, só se pode ser punido pela prática de um fato que a lei expressamente prevê como crime; pelo segundo, o crime deve ser imputável ao autor, em termos pessoais. No Direito Penal democrático, a responsabilidade aparece sempre ligada ao princípio da culpa, no sentido de que só podemos ser responsabilizados, por aquilo que praticamos em termos que legitimem um juízo de culpa (BETTIOL, ob. cit., págs. 34, 163 e 164).

A censura pessoal, em que consiste o juízo de culpa, pressupõe, ao lado da imputabilidade, seja possível ao autor conhecer a ilicitude de seu procedimento, prever-lhes todas as conseqüências e agir de maneira diversa. Não há, destarte, culpa, sem potencial consciência da antijuridicidade, sem previsibilidade dos resultados não queridos e sem exigibilidade de comportamento conforme ao Direito. E sem culpa nenhuma sanção penal é aplicável.

O princípio do nulla poena sine culpa deve presidir todo o sistema punitivo liberal, máxime no domínio da criminalidade política. Próprio dos Estados totalitários é fundar a pena, não na culpabilidade, mas na periculosidade da ação ou do agente. Foi o que se viu no nacional-socialismo, depois que a reforma de 1935 substituiu - princípio da legalidade, pelo critério de considerar crime toda ação atentatória ao são sentimento do povo alemão. Foi também - que ocorreu na União Soviética, com o Código Penal de 1926, reputando perigosas as ações dirigidas contra a estrutura do Estado ou lesivas à ordem jurídica criada pelo regime dos trabalhadores e camponeses (art. $6^{\circ}$ ). Ainda hoje, embora restaurado o princípio da reserva legal pelo Código Penal de 1960 (art. 4. ${ }^{\circ}$ ), a idéia de periculosidade é o fator preponderante no sistema repressivo soviético. É que a legalidade ali, além de não limitar o poder estatal, é meio para a realização dos fins da ditadura do proletariado. O Direito Penal marxista deve assumir uma intenção de classe, na medida em que é instrumento de força para a defesa das posições conquistadas pelos trabalhadores através da revolução. Pune-se o homem não pela culpa. mas porque sua ação é, de per si, objetivamente perigosa, ou porque ele próprio é considerado perigoso para a ordem 
estabelecida (BETTIOL, ob. cit., págs. 71 e 74). Nas democracias, ao contrário, a periculosidade é mero critério complementar, para determinar a forma de execução da pena ou para a imposição de medida de segurança aos inimputáveis.

c) Se, pelos princípios já expostos. a sanção penal assenta-se na prática de um fato lesivo a um bem ou interesse tutelado, previsto em lei como crime e pela qual o seu autor pode ser objeto de censura, a pena, nos Estados de Direito, tem de ser proporcionada à importância do valor ofendido e à culpabilidade do agente. A proporcionalidade, em relação ao bem ou interesse jurídico lesado ou ameaçado é estabelecida pelo legislador ao pré-fixar a qualidade e a quantidade da pena, em seus limites mínimo e máximo; a proporcionalidade, quanto à culpa, é averiguada pelo juiz, em função do grau de censurabilidade de que o autor do crime possa ser objeto.

A pena, assim, apresenta-se como dupla resposta: resposta à antijuridicidade, na qual prepondera o aspecto social, com a qualificação do fato como lesivo de um interesse comunitário; resposta à culpabilidade, em que prevalece o aspecto pessoal, com o estabelecimento da censura ao agente. Sendo essencialmente resposta, a pena não decorre da necessidade de defesa social, pela intimidação ou pela ressocialização do delinqüente. Estes objetivos não devem influir nos momentos da sua cominação e da sul aplicação. A intimidação não justifica sanções exasperadas, até porque não é o rigor das penas, mas a certeza da punição que realiza a prevenção geral. A ressocialização do delinqüente interessa à fase executória da pena privativa de liberdade, no sentido de adequá-la à personalidade do agente e, sem desrespeito à sua duração máxima, torná-la mais flexível, quanto a forma de cumprimento, segundo a periculosidade do agente (sursis, escolha do estabelecimento, livramento condicional, etc.). Na síntese de BETTIOL, "a pena é uma reação contra o deliło, mas uma reação pessoal, inspirada por critérios ético.retributivos, proporcionada à gravidade do crime cometido, determinada no tempo e executada de modo a permitir também a reeducação do delinqüente, finalidade que, dizendo respeito à execução da pena, não afeta sua natureza ontológica (ob. cit., pág. 129).

E, realmente, indispensável que a pena seja precisa e determinada no tempo, para evitar-se arbítrios de caráter político. Uma pena indeterminada ofende os princípios fundamentais de um Estado de Direito, em que toda a limitação da liberdade individual deve ser temporalmente delimitada (idem, pág. 171). Só a pena como resposta satisfaz esta exigência democrática. A pena, como mera providência de prevenção especial, necessariamente parte, quanto à 
sua escolha e duração, do objetivo de ressocializar o criminoso. Ora, isto conduz a aceitação de uma pena indeterminada, expressão de concepções políticas totalitárias.

Para o legislador, resulta da essência da pena, como resposta, - imperativo de estabelecê-la em correspondência à gravidade da infração, segundo os sentimentos comuns. Da finalidade da pena, como meio recuperatório, decorre-lhe a proscrição de uso de medidas que comprometam tal objetivo. Os elaboradores do Decreto-Lei 898/ 69 não se ativeram a estas limitações. As penas são de aberrante rigor, relativamente à gravidade das infrações. Basta lembrar que a ofensa pública, por palavras ou escrito, a chefe de governo de nação estrangeira implica em reclusão de dois a seis anos (art. 21). Ora, a qualquer juiz repugnaria aplicar semelhante sanção, v.g., ao estudante, que escrevesse num muro palavras ofensivas ao ditaclor de uma republiqueta africana qualquer. Mesmo aplicada no grau mínimo, a pena seria iníqüa, tendo em vista a não admissibilidade do sursis para as infrações políticas (art. 75). De outra parte, com a absurda cominação das penas de prisão perpétua e de morte para vários crimes contra a Segurança Nacional, além de contrariadas as tradições de nosso Direito, fica comprometido o ideal ressocializador. Perpétua a privação da liberdade, de nada vale ao delinqüente recuperar-se, posto que não voltará a usufruir da respiração do ar social. E a pena de morte, sobre ser a completa negação do sentido reeducador, constitui-se em autêntico instrumento de opressão. (BETTIOL, ob. cit., pág. 173).

Não se compreende, ainda, porque, além da pena capital, a privação de liberdade seja a única providência repressiva, de que se utiliza ○ Decreto-Lei 898/69. No Direito Penal contemporâneo, a prisão está em franca crise. No século XIX acreditava-se em sua eficácia ressocializadora; hoje é ela encarada como fator criminógeno. Traía-se do resultado natural da evolução da penologia: da mesma forma que as penas corporais, cruéis e infamantes, cederam passo para as penas priavtivas de liberdade, estas, agora, devem dar vez a outras sanções, patrimoniais ou restritivas de liberdade. Não se trata de abolir a privação de liberdade para os casos mais graves, merecedores de repressão enérgica, mas o de usar a prisão como último recurso, conforme recomendou Congresso Internacional de Direito Penal (Rev. de Direito Penal, n. ${ }^{\circ}$ s 15/66, pág. 82). Se tal é a tendência do Direito Penal comum, com maior razão, deve prevalecer quanto aos crimes políticos. Afora as formas de terrorismo, muitos destes crimes não se revestem de extrema gravidade. Daí a afirmação de HUNGRIA, de que se explica, assim, "que entre todos os povos cuiltos, na época moderna, certos favores de que gozam tais 
crimes, quando não sejam simples máscara a delinqüência comum, se fornassem uma tradição, que só a intolerância dos governos divorciados da opinião pública ou dos regimes mal consolidados pode abstrair. Segundo um princípio integrado na consciência jurídica universal, só ultimamente rompido com a fúria liberticida dos governos totalitários (de que a Rússia soviética ainda nos dlí um triste e alarmante exemplo), a pena de morte não é aplicável ou é sempre comutada, quando de se trate de criminosos poííticos. São a estes reservados, sistematicamente benefícios especiais: custódia honesta, anistia, direito de asilo ou não extradição" (ob. cit., vol. I, pág. 170).

9. A efetiva realização dos princípios básicos do Direito Penal democrático depende de adequadas garantias processuais. No Estado de Direito, o processo penal não é um instrumento de perseguição aos dissidentes políticos, mas um meio para a tutela da liberdade substancial e processual do réu. Trata se de consequiência inelutávl do princípio de que a democracia recebe sua legitimidade da pessoa humana singular. Nos regimes discricionários, pela prevalência dos interesses da comunidade racial ou da sociedade de classe, o processo penal inspira-se na idéia de desinfecção social, através de combate a elemntos tidos por "anti-sociais". Nista perspectivaí o processo penal do nazismo aboliu a paridade entre as partes e aumentou os poderes do Ministério Público, para favorecer à acusação, ao mesmo tempo em que suprimia as garantias da magistrutura, ampliava os casos de prisão preventiva e limitava os recursos. No mesmo sentido orientou-se o totalitarismo soviético, que, embora já tenha abolido o princípio da presunção de culpa, de início adotado, ainda não reconhece a presunção de inocência, permitindo condenações em caso de dúvida. Nos regimes liberais, ao contrário, o processo penal, encarado como instrumento de tutela de valores éticos ou de defesa do Direito, caracteriza-se, em síntese, pelos princípios da plena publicidade da instrução; da liberdade pessoal do réu até a condenação definitiva; da paridade absoluta enîre a acusação e a defesa; da passividade do iuiz na coleta de provas e da contínua comunicação ao réu dos fatos por cuja prática é acusado, assim como das provas contra ele reunidas (BETTIOL, ob. cit., págs. 315 e 317).

Sem descer a minúcias que escapam ao âmbito deste trabalho, parece-me que quanto ao processo por crime contra a Segurança Nacional, cumpre dar ênfase às garantias de independência da magistratura, presunção de inocência e plenitude de defesa.

A independência da magistratura é condição mínima oara que o processo penal se constitua em relação jurídica triangular. Como 
- Estado, nos delitos políticos, figura como sujeito passivo, não se concebe que o próprio Estado apareça como juiz em causa própria, com sacrifício da imparcialidade, valor fundamental na função judicante. Esta contradição só é superada pela separação dos poderes, que informa a estrutura constitucional do Estado de Direito. A condição do Estado como sujeito passivo dos crimes políticos tem de circunscrever-se ao Estado-Administração, não se estendendo ao Estado-Juiz. A independência real da magistratura perante os órgãos do Poder Exicutivo é, pois, o requisito básico das garantias processuais, sobretudo nos momentos de inquietude política do mundo contemporâneo.

Da presunção de inocência decorre que, em caso de dúvida, os conflitos entre o jus puniendi e $\circ$ jus libertatis hão de ser decididos em favor do último. $O$ in dubio pro reo deve inspirar, quanto aos crimes políticos, nem só a apreciação da prova, como a própria exegese da norma. E impõe também que a prisão preventiva seja limitada aos casos de extrema necessidade e dependente de fundada suspeita contra o réu.

A plenitude da defesa pressupõe o acesso a todos os recursos e remédios, contra a ilegalidade e 0 abuso do poder. Nega-a a proibição do habeas corpus quanto aos crimes políticos, restrição injustificável, posto que os excessos não constituem monopólio das autoridades encarregadas da repressão à criminalidade comum, apresentando-se, com maior freqüência, na atividade repressora dos crimes políticos, mercê das influências de paixões momentâneas. Inerente à plenitude da defesa é, ainda, a comunicação da acusação ao indiciado, para permitir-lhe preparar defesa adequada. Sem isto, não há processo penal digno deste nome. Mas tal garantia é ilusória se, comunicada a acusação ao indiciado, não se the permitir imediato contacto com defensor de sua escolha. Impõe-se, assim, abolir a incomunicabilidade absoluta imposta aos presos por suspeita de crime político (Decreto Lei 898/69, art. 59, § $1 .^{\circ}$ ), assegurando-se a plenitude do direito que $\circ$ art. $89, n .^{\circ}$ III, da Lei n. ${ }^{\circ} 4.215 / 63$, assegura aos advogados.

10. De tudo o que foi exposto, cabe extrair as seguintes conclusões e propostas:

1 - Estado de Direito é o que se autolimita para respeitar as liberdades individuais. Estas são direitos do homem, com valor supraconstitucional, no sentido de obrigar moralmente os legisladores a respeitá-los e de servir como critério decisivo aos juízes, na interpretação e aplicação das normas. 
11 - Os direitos humanos acham-se enumerados na Declaração Universal da ONU e compreendem direitos fundamentais e direitos complementares. Os direitos fundamentais relacionam-se à igualdade, às liberdades da pessoa, ao direito político de votar e ser votado e ao direito de propriedade. Os direitos complementares, necessários ao exercício dos fundamentais, dizem respeito à liberdade de pensamento e aos direitos econômicos. A liberdade de pensamento compreende as liberdades de imprensa, de associação e de reunião. Os direitos econômicos expressam-se no direito ao trabalho, no direito sindical, no direito de greve e na liberdade de comércio e indústria.

III - No Estado de Direito, a Segurança Nacional constitui meio de garantir as liberdades públicas. Protege-se o Estado, para que este possa garantir os direitos individuais. A legitimidade da incriminação de atentados à Segurança Nacional repousa o princípio de que, só por meios jurídicos, podem ser alteradas as instituições estabelecidas pelo povo, através de legítimos representantes, livremente escolhidos.

IV - E mister que a lei defina, limitativamente, Segurança Nacional. O conteúdo desta não deve continuar ao arbítrio do Poder Executivo. No Estado de Direito, a Segurança Nacional circunscreve-se à incolumidade do Estado e à incolumidade dos direitos políticos dos cidadãos. A incolumidade do Estado concerne à sua soberania, estrutura constitucional, funcionamento e independência de poderes. Os direitos políticos do cidadão garantem aos eleitores a prerrogativa de seleção das pessoas, às quais se deva confiar a elaboração das leis e a suprema gestão da coisa pública.

V - Como o Estado de Direito visa assegurar o indivíduo a inviolabilidade de sua esfera de autonomia, o crime há de decorrer de fatos externos, ofensivos à bens ou interesses jurídicos. Da mesma forma, o ilícito político não pode consistir em ter-se idéias dissidentes das do regime, nem na mera posse de meios para formá-las. Indispensável, pois, assegurar expressamente a liberdade de imprensa e de publicações, sem censura prévia, com responsabilidade administrativa e penal a posteriori, por abusos eventualmente cometidos.

VI - As infrações de direito comum, como homicídio, lesões corporais, ofensas à honra, seqüestros e roubos, só podem ser erigidas à categoria de crimes políticos, quando praticadas com motivação desta natureza. Ao descrever os fatos que constituem delitos contra a Segurança Nacional, embora ofensivos de bens jurídicos privados, a lei deve mencionar expressamente o móvel político. Não é correto o critério da legislação atual de considerar como crimes po- 
líticos, fatos como assaltos a bancos cometidos por motivações diversas. Em casos tais, a repressão faz-se pelos dispositivos incriminadore do Direito Penal comum.

VII - No Estado de Direito, são perfeitamente definidas as relações entre autoridade e liberdade. As leis, portanto, têm de descrever os fatos puníveis de maneira inequívoca, sem deixar margens a dúvidas sobre a sua proibição. Destarte, é dever do legislador evitar expressões dúbias ou formulações genéricas. Definições vagas, como fazer propaganda subversiva, favorecem o arbítrio, pela elasticidade de que se revestem.

,VIII - As penas criminais não têm por fundamento a periculosidade social do fato ou do seu autor, como ocorre nos regimes totalitários. A responsabilidade penal, nas democracias, resulta da culpa. $O$ homem só é responsabilizado pelo que praticou, se for passível de censura pesscal, ante 0 reconhecimento in concreto, de que poderia ter agido de maneira adequada ao Direito. A responsabilidade objetiva tem de ser proscrita, também na criminalidade política.

IX - A pena é resposta racional à ilicitude do fato e à culpa de seu autor. Na sua execução visa reeducar o condenado. Disto decorre, para o legislador, o imperativo de proporcionar a pena à gravidade do crime e de evitar medidas que comprometam o ideal de reeducação. As atuais penas da lei de Segurança Nacional são aberrantemente rigorosas e desproporcionadas às ofensas. As penas de morte e de prisão perpétua têm de ser abolidas, por negarem o objetivo ressocializador; as privativas de liberdade, reservadas aos delitos mais graves e executadas sem rigor penitenciário.

$X$ - O processo penal não é meio de perseguir dissidentes políticos. No Estado de Direito, é instrumento de tutela da liberdade e da dignidade do réu, bem como dos valores éticos em que se consubstancia a Justiça. Tais finalidades só se cumprem mediante - respeito à independência da magistratura, à presunção de inocência do réu e à amplitude de sua defesa. Impōe-se, assim, a restauração dos predicamentos da magistratura, condição fundamental da imparcialidade na função judicante, confiando-se a juizes independentes também o julgamento dos crime políticos. Do princípio da presunção de inocência decorre a necessidade de limitar-se a prisão preventiva, ãos casos em que haja fundada suspeita contra o réu. Impossível aceitar a privação de liberdade como corriqueiro meio de investigação de crimes políticos. Incompatível com a plenitude de defesa é a proibição do habeas corpus, quanto aos delitos desta ordem. A ilegalidade e o abuso de poder não são monopólios dos órgãos de 
iepressão da criminalidade comum. Apresentam-se, até com maior freqüência, na atividade repressora dos delitos políticos, pela influência das paixões de momento. Indispensável, pois, a tantas vezes pedida restauração da plenitude do habeas corpus. Nem há amplitude de defesa, se o preso fica impedido de comunicar-se com o advogado de sua escolha. A pronta comunicação com o profissional é indispensável ao preparo de defesa adequada. Em conseqüência, abusiva apresenta-se a incomunicabilidade absoluta, a que, atualmente, podem ser submetidos os suspeitos de crimes contra a Segurança Nacional. 